\title{
The importance of apparel product attributes for female buyers
}

\author{
Ernest J North, Retha B de Vos and T Kotzé
}

\section{OPSOMMING}

Die doel van hierdie artikel is om die bevindinge van 'n empiriese ondersoek te rapporteer wat uitgevoer is om vroulike verbruikers se aankoopbesluite vir ' $n$ kledingstuk te ontleed wat gebaseer is op die waarde wat hulle aan sekere eienskappe van die produk heg. Alhoewel menige studies in die verlede verbruikers se houdings jeens produkte en hul eienskappe gemeet het, is die moontlikheid van die effek van interaksie tussen die attribute oorgesien. In die Suid-Afrikaanse konteks het die literatuurstudie getoon dat daar ' $n$ behoefte is aan ' $n$ studie om te bepaal wat die waarde is wat vroulike verbruikers aan sekere produkeienskappe heg voordat aankoopbesluite gefinaliseer word.

'n Vraelysopname is as primêre data-insamelingsmetode gebruik waartydens die respondente versoek is om aan te toon wat hul voorkeure is vir dertig gepaarde kombinasies van die produk en sy eienskappe. Hierdie studie het op vier eienskappe, naamlik handelsmerk, styl, kleinhandelaar en prys gefokus. Hipoteses is geformuleer en voorkeurkeuse-ontleding ("conjoint analysis") is vir die ontleding van data gebruik. Die bevindinge toon aan dat daar beduidende verskille is in die waardes wat vroulike verbruikers heg aan die eienskappe van 'n kledingstuk voordat aankoopbesluite geneem word.

- Prof E North

Department of Marketing and Communication Management, University of Pretoria

\section{- Ms MB de Vos}

Commercial Methods and Training Manager

Peugeot Motors South Africa

- Mr T Kotzé

Department of Marketing and Communication

Management, University of Pretoria

\section{INTRODUCTION}

Although the apparel industry seems to be in the maturity stage and growth is slow, fashion trend cycles are accelerating - nowadays the average successful clothing trend lasts only six to twelve weeks. The presence of more and more brands has created a competitive environment unheard of in the past (Rutter \& Edwards, 1999). A major change in today's society is the expanded role of female consumers as more and more woman enter the labour market (Schiffman \& Kanuk in Shim \& Kotsiopulos, 1993), resulting in higher disposable income for female consumers. Consequently they are recognised by apparel marketers as a sought after target market (Cassill \& Drake, 1987).

Like many other items, apparel products are composed of many physical characteristics, which are perceived differently by various consumers. When considering a product purchase, consumers tend to compare and contrast alternative products made up of different attribute combinations. Their preferences for items of apparel may depend on the joint influence of price and product attributes such as quality, style, and brand. According to Lang and Crown (1993), past research mostly used survey methods to directly measure consumers' attitudes towards products and their attributes. The possibility of interaction effects between attributes is usually overlooked.

The aim of this article is to report the findings of an empirical research study that was done to analyse female consumers' apparel purchasing decisions, on the basis of the value they attach to certain product attributes. The identification of these values could assist marketers to gain a better understanding of the decision-making processes of female consumers and to predict the future actions of these consumers when it comes to apparel purchases.

\section{THEORETICAL OVERVIEW}

Because people engage in consumption activities every day marketers are challenged to determine exactly what customers need, and to find ways to meet these needs as efficiently as possible. Marketing is therefore regarded as a customer-centric action that bridges the gap between what the company has to offer and what the market or customers want (Campbell \& Butaney, 1996).

From a marketing point of view the study of consumer behaviour is important in helping to understand and predict consumer demand for products as well as 
brand preferences (Antonides \& Van Raaij, 1998:1). Retailers and marketers would also benefit from an understanding of consumers' shopping orientations and patronage behaviour since this would enable them to maximise consumer satisfaction and retail sales (Shim \& Kotsiopulos, 1993).

Over the years students of marketing have taken a keen interest in consumer perceptions of value (Zeithaml, 1988; Sheth et al, 1991; Woodruff, 1997 in Sheth and Sosodia, 1999). Many aspects, such as price, aesthetics and quality are important considerations when buying decisions for clothing items are made (Eckman et al, 1990; Lang \& Crown, 1993). Criteria that have been found to influence the evaluation and buying decision of apparel include price, care requirements, brand, product composition (ie style and colour), store image, and advertising image. These authors have classified the criteria as either intrinsic or extrinsic. Intrinsic cues are product attributes that cannot be changed or manipulated without also changing the physical characteristics of the product itself. Product attributes that are not component parts of the physical product but that are applied by the manufacturer or retailer are extrinsic cues. According to Eckman et al (1990), price and brand are the attributes most frequently used by consumers in assessing apparel. When all the studies cited are considered as a whole, intrinsic characteristics seem to be more important to consumers than extrinsic characteristics. This pattern is consistent with research that has specifically examined the extrinsic/intrinsic issue (Hatch \& Roberts; Syzbillo \& Jacoby; Wheatley et al in Eckman et al, 1990).

Beaudoin et al (2000) identified 12 attributes that correlated with attitudes when purchasing apparel, namely: good fit, durability, ease of care, favourable price, comfort, quality, colour, attractiveness, fashionableness, brand name, appropriateness for occasion, and choice of styles. Dickerson (in Beaudoin et al, 2000) investigated the relative importance that consumers attach to five garment attributes when making purchasing decisions, namely: price, care, country of origin, quality, and style. Shim and Kotsiopulos (1993) researched the apparel shopping orientation of consumers on the basis of nine factor labels, namely: appearance/fashion conscious, brand conscious, convenience/time-conscious, shopping mall-oriented, local store-oriented, apathetic toward "Made in the USA", catalogue-oriented, economy/price conscious, and credit-oriented.

What is lacking throughout this research is any attempt to understand how multiple criteria, both intrinsic and extrinsic, are combined in the purchasing decision-making process (Eckman et al, 1990:14). In this study the combined influence of the following intrinsic and extrinsic attributes will be examined: brand, style, retail store and price. Each of these attributes will be briefly discussed in the following paragraphs.

\section{Brand name}

The demand for brand name apparel products has risen steadily over the past decade (Huddleston \& Cassil, 1990). For the retailer, branded products can mean better profits and more store traffic. Over time brand name products develop a certain reputation or image. This reputation or image conveys information that is useful to consumers in their pre-purchase decision making process. Forsynthe (1993) found that the brand name was associated with a higher price when shoppers were asked to examine three identical shirts that differed only in their labels. Roa and Monroe (in Huddleston, 1990) found that consumers use a brand name as a cue to assess quality, thus justifying a willingness to pay a higher price for a product. In this study the utility values of three brand types were examined, namely designer brand, private label brand and unbranded.

\section{Style}

According to the Fairchild Dictionary of Fashion (in Perna, 1987:48), fashion is the custom or style of dressing that prevails among any group of persons. It is the style of the present, which may last for a year or two or a number of years. A high fashion style is the look of the moment. If a look or trend persists long enough it becomes a classic. A classic style is a look that is always available in some form that is appropriate for many occasions, and acceptable to many consumer groups (Brannon, 2000:7). Some consumers make choices concerning apparel on the basis of comfort and practicality. Therefore a third style can be identified, namely a comfortable fit. The relative importance of these three styles was examined in this study.

\section{Retail store}

By definition a retailer (retail store) is "any business establishment that directs its marketing efforts toward the final consumer for the purpose of selling goods and services" (Lewison in Burns \& Bryant, 1997:333). Retailers range in size from small sole proprietorships that cater to a local market, to large corporate ownership groups (Burns \& Bryant, 1997:333). In this study, the utility values of the following four store types were investigated: Chain store organisations own and operate several retail store units that sell similar lines of merchandise by a standardised method and function under a centralised form of organisational structure, centralised distribution and standardised store décor and layout. A speciality store concentrates on a limited number of complementary merchandise categories and provides a high level of service in an area that is typically less than 8000 square feet. Speciality stores focus on a narrow market segment or niche. Consumers are attracted to speciality stores by deep assortments, personal attention and a more intimate store atmosphere (Levy \& Weitz, 1998:36). A discount store is one that sells brand name merchandise at below traditional retail prices and includes apparel merchandise priced in the budget wholesale price zone. Through mass-merchandising strategies, discount retailers are able to keep their prices lower than 
those of other retailers. A branded speciality store focuses on a specific type of merchandise, but offers it only in its own brand to a well-defined target market. A limited but deep assortment is carried (Burns \& Bryant, 1997:336).

\section{Price}

Price and quality have different and differential effects on perceived value for money. Some consumers perceive value when the price is low. Others perceive value when there is a balance between quality and price (Cravens et al and Monroe in Sweeney \& Soutar, 2001). There are typically five price zones in the apparel industry, namely designer, bridge, better, moderate and budget or mass (Burns \& Bryant, $1997: 111)$. In this study, the focus was on four levels of price, namely designer, better, moderate and budget.

In the South African context, the literature search revealed that a limited number of studies have ever been carried out on the subject of consumer decisionmaking with respect to the buying of apparel. Terblanche (1990) conducted a life-style typification study of female students with specific reference to fashion awareness and clothing orientation. Auret (1990) did a study on the needs and purchasing behaviour of female students at the University of Stellenbosch. Furthermore, the use of conjoint analysis as a research method in this field seems to be in its infancy stage. One recent study (Burger \& Herbst, 2002) did, however use a conjoint approach to determine the importance of certain clothing attributes, such as style, price, brand and outlet choice during the decisionmaking process of teenagers when purchasing denims. Two hundred and thirteen (13-16 years) secondary school pupils were presented with 25 hypothetical paired-wise product profiles. The results indicated, inter alia, that the brand name (for example Levi or Diesel) is the most important attribute teenagers consider before making a purchase. Diesel was the most popular brand, followed by Calvin Klein.

The need for a study in South Africa on the value female consumers attach to certain attributes when making apparel purchasing decisions is evident from the foregoing. More specifically, the joint effect of several product attributes on the final product choice for apparel will be examined in this study.

\section{PROBLEM STATEMENT}

Fashion designers and other fashion icons have traditionally dictated fashion trends. However, over the past ten years consumers have become more demanding and the focus of marketing in the apparel industry has had to shift to what the consumer wants (Brannon, 2000:16). Retailers need a better understanding of what consumers value when they make purchase decisions. This understanding will lead to a more accurate merchandise mix and more specifically targeted promotional and advertising campaigns. It is important to research the value consumers attach to certain attributes when making apparel purchase decisions. This will enable apparel manufacturers and retailers to plan and implement their strategies more effectively. It is also necessary to understand more about the behavioural characteristics of consumers. This could provide insight into the type of apparel purchasing decisions that the various types of consumers will make.

Conjoint analysis has been used in research for many years (Green \& Spirnivasan, 1990). Hair et al (1998:388) state that the application of conjoint analysis in the United States has been paralleled in other parts of the world as well as in Europe. However, it does not appear to have attracted the attention of local researchers until recently and it is not clear why local academic researchers in particular do not make more use of conjoint analysis. The lack of research results in this field in South Africa poses a potential dilemma to many local marketers. Scientific research results could provide managers with the necessary information on where their marketing focus should be and what is important for each group of consumers. Furthermore, managers would like to know the answers to specific questions such as the value that consumers in different age groups (or in various brackets of monthly expenditure on apparel) attach to attributes such as price, brand and retail outlet before making a final purchasing decision. This could help them to gain a deeper understanding of how apparel choices could be linked to the behavioural traits of consumers. It could also provide management with a better basis for choosing the correct merchandise mix and advertising focus.

\section{RESEARCH APPROACH}

\section{Research objectives and hypotheses}

The literature review revealed many aspects that require further investigation, for example answers need to be found to the following: What value do consumers attach to the various attributes (as described in the literature review) when they make apparel purchasing decisions; do consumers value certain attributes more highly than others; and is there a relationship between the value consumers attach to these attributes and other consumer behavioural aspects, such as age and monthly expenditure on apparel?

In an attempt to answer these questions the primary purpose of the research was to analyse the value female consumers of apparel items attach to certain attributes of the products they are considering buying. The study therefore attempted to determine how important each of the attributes is when female consumers make apparel purchase decisions.

The secondary objectives of the research were to analyse the relationship between age and the four attributes being studied, and to analyse the relationship between monthly expenditure on apparel and these four attributes. 
The above gave rise to the formulation of the following hypotheses for this study:

$H_{\mathrm{a}} \quad$ There is a significant difference between the importance consumers attach to brand, style, retail outlet and price as attributes of apparel when making purchasing decisions (primary hypothesis). The secondary hypotheses are:

$H_{1} \quad$ There is a significant difference in the level of importance that various age groups attach to style as an attribute.

$\mathrm{H}_{2} \quad$ There is a significant difference in the level of importance that various age groups attach to brand as an attribute.

$\mathrm{H}_{3} \quad$ There is a significant difference in the level of importance that various age groups attach to price as an attribute.

$\mathrm{H}_{4} \quad$ There is a significant difference in the level of importance that various age groups attach to retail outlet as an attribute.

$\mathrm{H}_{5} \quad$ There is a significant difference in the level of importance that respondents in different categories of monthly expenditure on apparel items attach to brand as an attribute.

$H_{6} \quad$ There is a significant difference in the level of importance that respondents in different categories of monthly expenditure on apparel items attach to style as an attribute.

$\mathrm{H}_{7} \quad$ There is a significant difference in the level of importance that respondents in different categories of monthly expenditure on apparel items attach to retail outlet as an attribute.

$H_{8} \quad$ There is a significant difference in the level of importance that respondents in different categories of monthly expenditure on apparel items attach to price as an attribute.

In each of these secondary hypotheses the behavioural characteristic is the independent variable, whereas the attribute is the dependent variable.

\section{Sampling}

According to Sudman and Blair (1998:338) the population is the entire set of elements being studied and should be defined in terms of time, place element and sample unit. For this study the population included women in two provinces in South Africa (Gauteng and Mpumalanga) between the ages of 16 and 65 . A sample is a subset of the population of interest (McDaniel \& Gates, 2001:328). In this study a convenience, non-probability method of sampling was used. The sample consisted of the population elements that the researcher could study most conveniently, and was based on the selection of respondents at the place where and the time when the study was performed (Dillon et al, 1993:229). The considerations listed below were taken into account when determining the sample size of 250 women:

- This was a descriptive study.

- Differences in preference between groups of people were measured. The data were analysed at subgroup level.

- A 95\% confidence level was required.

- This was an academic study and was subject to budgetary constraints.
The sample size for conjoint studies normally ranges between 150 and 1200 respondents (Orme, 1998).

\section{Collection and analysis of data}

This study was viewed as a formal study in which a questionnaire was used as the data collection instrument and conjoint analysis as the principal method of data analysis. The information gathered from the questionnaire consisted of quantitative continuous data (eg on age) and qualitative ordinal data (eg according to a Likert-type scale). The aim of this study was to determine what attributes are important to female consumers when apparel purchasing decisions have to be made. In order to accomplish this, attributes had to be identified and each attribute had to be subdivided into a number of levels. Respondents were asked to make trade-offs between attributes at various levels, enabling them to make complex decisions not only on one factor, but on several factors "jointly". The attributes and levels used in this study are shown in Table 1.

\section{TABLE 1: $\quad$ ATTRIBUTES AND LEVELS}

\begin{tabular}{|l|l|}
\hline \multicolumn{1}{|c|}{ Attribute } & \multicolumn{1}{c|}{ Level } \\
\hline Brand & Designer brand \\
\cline { 2 - 2 } & Private label brand \\
\cline { 2 - 2 } & Unbranded \\
\hline Style & High fashion \\
\cline { 2 - 2 } & Classical \\
\cline { 2 - 2 } & Comfortable \\
\hline Retail store & Large clothing retail chain \\
\cline { 2 - 2 } & Discount clothing retailer \\
\cline { 2 - 2 } & Speciality clothing store \\
\cline { 2 - 2 } & Branded speciality store \\
\hline Price & Designer: R350 \\
\cline { 2 - 2 } & Better: R260 \\
\cline { 2 - 2 } & Moderate: R170 \\
\cline { 2 - 2 } & Budget: R80 \\
\hline
\end{tabular}

Secondary data in the form of published academic articles were used to identify possible attributes. A process of selection was followed to identify the four attributes used in this study. This process included ease of describing the attribute to respondents as well as the frequency with which the attribute had been used in previous research studies.

As a method of analysing data, conjoint analysis is a technique used to establish the relative importance of different attributes in the provision of a product or service. Respondents indicate their preference for a series of hypothetical multi-attribute alternatives, which are typically displayed as profiles of attributes. The responses to these profiles are analysed to yield esti- 
TABLE 2:

EXAMPLES OF UTILITY VALUES

\begin{tabular}{|l|c|c|c|c|c|}
\hline $\begin{array}{c}\text { Attribute } \\
\text { (Brand) }\end{array}$ & $\begin{array}{c}\text { Utility } \\
\text { value }\end{array}$ & $\begin{array}{c}\text { Attribute } \\
\text { (Colour) }\end{array}$ & $\begin{array}{c}\text { Utility } \\
\text { value }\end{array}$ & Price & $\begin{array}{c}\text { Utility } \\
\text { value }\end{array}$ \\
\hline Brand A & 40 & Red & 20 & R50 & 90 \\
\hline Brand B & 60 & Blue & 10 & R75 & 40 \\
\hline Brand C & 20 & Pink & 0 & R100 & 0 \\
\hline
\end{tabular}

TABLE 3: $\quad$ AVERAGE UTILITY VALUES

\begin{tabular}{|c|c|c|c|c|c|}
\hline \multicolumn{2}{|r|}{ Brand } & & \multicolumn{2}{|r|}{ Retail store } & \\
\hline \multirow[t]{2}{*}{ Level: } & Designer brand & 18 & Level: & Large clothing chain & 22 \\
\hline & Private label brand & 19 & & Discount clothing retailer & 15 \\
\hline \multirow{2}{*}{\multicolumn{2}{|c|}{ Unbranded }} & 7 & & Speciality clothing store & 17 \\
\hline & & & & Branded speciality store & 23 \\
\hline \multicolumn{2}{|r|}{ Style } & & \multicolumn{2}{|r|}{ Price } & \\
\hline \multirow[t]{4}{*}{ Level: } & High fashion & 80 & Level: & R80 & 58 \\
\hline & Classical & 70 & & R170 & 37 \\
\hline & \multirow[t]{2}{*}{ Comfortable } & 14 & & R260 & 20 \\
\hline & & & & R350 & 0 \\
\hline
\end{tabular}

TABLE 4: $\quad$ CALCULATING ATTRIBUTE IMPORTANCE

\begin{tabular}{|l|c|c|}
\hline \multicolumn{1}{|c|}{ Attributes } & Range & Percentage Importance \\
\hline Brand (B-C) & $60-20=40$ & $(40 / 150) \times 100=26,7 \%$ \\
\hline Colour (Red - Pink) & $20-0=20$ & $(20 / 150) \times 100=13,3 \%$ \\
\hline Price (R50 - R100) & $90-0=90$ & $(90 / 150) \times 100=60,0 \%$ \\
\cline { 2 - 3 } & 150 & $100 \%$ \\
\hline
\end{tabular}

TABLE 5: RESULTS OF WILCOXON'S SIGNED RANKS TESTS BETWEEN ALL PAIRS OF ATTRIBUTE IMPORTANCE

\begin{tabular}{|l|c|c|c|c|c|c|}
\hline $\begin{array}{c}\text { Test } \\
\text { statistics }\end{array}$ & $\begin{array}{c}\text { Style \& } \\
\text { brand }\end{array}$ & $\begin{array}{c}\text { Retail store } \\
\text { \& brand }\end{array}$ & $\begin{array}{c}\text { Price \& } \\
\text { brand }\end{array}$ & $\begin{array}{c}\text { Retail store \& } \\
\text { style }\end{array}$ & $\begin{array}{c}\text { Price \& } \\
\text { style }\end{array}$ & $\begin{array}{c}\text { Price \& } \\
\text { retail store }\end{array}$ \\
\hline $\mathbf{Z}$ & $-10,67^{\mathrm{a}}$ & $-5,34^{\mathrm{a}}$ & $-7,22^{\mathrm{a}}$ & $-10,42^{\mathrm{b}}$ & $-6,01^{\mathrm{b}}$ & $-4,47^{\mathrm{a}}$ \\
\hline $\begin{array}{l}\text { 2-tailed } \\
\text { p-value }\end{array}$ & $<0,000$ & $<0,000$ & $<0,000$ & $<0,000$ & $<0,000$ & $<0,000$ \\
\hline
\end{tabular}

Based on negative ranks

Based on positive ranks

TABLE 6: $\quad$ AVERAGE ATTRIBUTE IMPORTANCES FOR FIVE AGE GROUPS

\begin{tabular}{|c|c|c|c|c|c|}
\hline Age groups & $\mathbf{n}$ & Style & Brand & Price & Retail store \\
\hline $16-20$ & 65 & 61,41 & 11,42 & 11,89 & 15,28 \\
\hline $21-30$ & 72 & 35,50 & 13,66 & 31,41 & 19,43 \\
\hline $31-40$ & 35 & 43,37 & 12,85 & 28,08 & 15,70 \\
\hline $41-50$ & 31 & 41,03 & 13,18 & 31,84 & 13,94 \\
\hline $51+$ & 23 & 35,60 & 11,71 & 37,31 & 15,38 \\
\hline Total & 226 & 44,94 & 12,63 & 25,94 & 16,49 \\
\hline
\end{tabular}


mates of the relative importance of the attributes and to build predictive models of consumer choice for new alternatives (Oppewal \& Vriens, 2000). The following three steps were followed in the execution of the conjoint analysis: firstly, the attributes were determined, secondly, the attribute levels were assigned, and thirdly, the scenarios (profiles of attributes) to present to the respondents were compiled (Van der Pol \& Rayn, 1996).

\section{Questionnaire design and practical execution of the study}

The design of a questionnaire to be used in a conjoint study hinges to a large extent upon the way the questions or simulations are presented to the respondents. The three methods of stimulus presentation most widely associated with conjoint analysis are the tradeoff, full profile and pair-wise comparison methods (Hair et al, 1998:574). In this study, the pair-wise method was used; this method is a combination of the first two methods. It is a comparison of two profiles where the respondents use a rating scale to indicate strength of preference for one profile versus the other. Only a few attributes are selected at a time in constructing the profiles. In the pair-wise comparison method the pairs are profiles which each contain multiple attributes. For practical reasons, all the possible combinations of stimuli cannot be used in a full-profile (factorial design) method. In this study it was therefore decided to use a fractional factorial design where a sample of the possible stimuli in a full-profile method was selected (Hair et al, 1998:574-576). For the pairwise comparisons a computer-generated program was used to select the optimal sets of pairs for the paper-and-pencil questionnaire. The Conjoint Value Analysis (CVA), Version 2.0 system provided the tools to design the thirty pair-wise comparisons of the profiles used in the study. The respondents were requested to indicate their preferences by ranking a number of different combinations of attribute levels on a ten-point Likert scale. These questions forced respondents to make trade-offs between product attributes and allowed the researcher to understand what is important to the respondent when making purchasing decisions on apparel. Figure 1 is an example of a computer-administered paired-comparison choice, which served as one of the 30 pair-wise questions in the questionnaire. The respondents were requested to indicate which profile (option A or B) they preferred, featuring price as an attribute.

Two hundred and twenty-seven female respondents eventually participated in the study. Respondents were recruited on university campuses, in shopping malls, at schools and at office blocks. Subjects were presented with a simulated shopping situation in which they were given thirty shirt choices to evaluate. Each shirt was presented by means of a sketch showing its style and a description of the brand, price and retail outlet.

Respondents were asked to choose between two shirts and rate their preference on a scale from 1 to 10 (1 indicated that they strongly prefer the left-hand shirt while 10 indicated that they strongly prefer the right hand shirt). The demographic details required included the town or city they reside in, age, monthly expenditure on clothing and highest level of education. The information gained here was primarily used in testing the secondary hypotheses.

\section{RESULTS AND DISCUSSION}

\section{Description of the respondents}

Descriptive findings indicate that the sample mainly consisted of "twenty something" females who reside in Mpumalanga. Of the 227 participants, 150 reside in

WHAT WOULD YOU PREFER?

A

Designer brand

Speciality store

R170
B

Unbranded

Discount retailer

R260

\section{CHOOSE A NUMBER TO INDICATE YOUR PREFERENCE}

Strongly prefer A

\begin{tabular}{l|l}
1 & \\
\hline
\end{tabular}

Indifferent
Strongly prefer B

\begin{tabular}{|l|l|l|l|l|l|l|l|l|}
\hline 2 & 3 & 4 & 5 & 6 & 7 & 8 & 9 & 10 \\
\hline
\end{tabular}

\section{FIGURE 1: PAIR-WISE QUESTION}


Mpumalanga, and 77 in Gauteng. The age of the respondents varied from 16 to 65 . Almost one third of the sample was between 21 and 30 years of age, while $51 \%$ were younger than 31 years of age. Only $10 \%$ of the respondents were in the over 51 -year category, and $14 \%$ were in the 41 to 50 year old category. The fact that the sample consisted mainly of younger respondents suggests that future research could aim to include more older apparel buyers.

Nearly $63 \%$ of the respondents indicated that they spend less than R500 per month on clothing, while only 3 respondents $(0,01 \%)$ indicated that they spend more than R1200 per month on clothing. Forty three percent of the respondents had completed some or all of their high school education, and $16 \%$ have a diploma. Thirty-three percent have obtained a tertiary qualification.

Conjoint analysis produces two types of outputs that are important for the purposes of data description and hypothesis testing, namely part-worth utilities and attribute importance. The nature of these two outputs requires further investigation.

\section{Part-worths and utility values}

A traditional conjoint analysis is, in fact, a multiple regression problem that is solved for each individual respondent who participates in a conjoint study (Orme, 2002a). The respondent's attractiveness or preference rating for a particular product profile forms the dependent variable, while the characteristics of the product (i.e. the specific attribute levels included in the profile) are the independent variables. The attribute levels are included in the regression analysis as "dummy variables". The beta coefficients estimated by the regression analysis are the part-worths for the different attribute levels (see Orme, 2002a for an example of traditional conjoint analysis using MS Excel).

A part-worth represents the preference or utility associated with a specific level of an attribute included in a conjoint profile, and is estimated for each respondent in a conjoint study (Hair et al, 1998:391). The utility value represents a respondent's overall preference for a particular product profile. In traditional conjoint analysis, utility values are usually calculated as the sum of the part-worths of the specific attribute levels included in a product profile (Hair et al, 1998:392). Therefore, the higher a part-worth (either positive or negative), the more impact it has on overall utility (Hair et al, 1998: 420).

Some authors do not explicitly distinguish between part-worths and utility values, but use the term "utility values" to refer to both (see Orme, 2002a; Orme, 2002b; Curry, undated). For simplicity sake, the latter convention was followed in this study.

Utility values are interval scaled data (Orme, 2002b), a fact that has important implications for their interpretation. Both Curry (undated) and Orme (2002b) emphasises that it is not correct to directly compare the utility value of one attribute level with that of another (even within the same attribute). The absolute values of utilities have no inherent meaning. One can only compare differences or gaps in utility values. The following hypothetical example taken from the Sawtooth Software (1996) user manual of the CVA 2.0 system illustrates this point. Suppose we have the following individual-level utility values for three attributes with three levels each (Table 2).

From the example above, it is not correct to say that Brand $C$ has the same desirability as the colour Red. It is also not correct to say that Brand $A$ has twice the preference rating of Brand $\mathrm{C}$. However, one may conclude that the differences in the utility values between brands B and A (60-40) are the same as the difference in the utility values between Red and Pink (20$0)$. This particular respondent should, therefore, be indifferent between Brand $A$ in a red colour $(40+20=60)$ and Brand B in Pink $(60+0=60)$ at the same price.

The best practice is therefore not to compare utility values directly, but rather to compare the relative attractiveness of different product profiles on the basis of their total summed utility values (Curry, not dated). Hair et al, (1998:421; 432-434) indicate that utility values can be plotted graphically to identify patterns and can also be used to identify market segments using cluster analysis.

It is also important to note that utility values may, in some cases, have negative values depending on how the utilities are scaled. Conjoint utilities are scaled to an arbitrary additive constant within each attribute (Orme, 2002a). In cases where so-called "effects coding" is used, utilities are scaled to sum to 0 and certain levels may then have negative utility values. However, just because a specific attribute level received a negative utility does not imply that this level was unattractive. In other cases, one of the utility values within each attribute is set to 0 and the remaining levels are set as contrasts with respect to 0 (see Orme, 2002a). Again, it is important to note that an attribute level with a utility value of zero does not imply that the particular level has no utility for respondents. Zero-level utilities simply refer to the least preferred level of each attribute; this does not mean that those least-preferred levels have no utility.

Utility values for the current study were calculated using the Ordinary Least Squares (OLS) method available in CVA 2.0 and were rescaled using the default "points" method. This method scales utilities in such a way that the sum of the utilities across all levels for an individual respondent is equal to the number of attributes times 100. The 'points' method scales utilities so that each respondent contributes the same weight to a calculated set of average utilities (Curry, not dated). The average utility values of the different attribute levels included in the conjoint design of the current study are listed in Table 3.

The information in Table 3 indicates, inter alia, that 
high fashion obtained the highest score for style; the branded specialty store the highest for retail store, and the figure of $\mathrm{R} 80$ the highest average utility score for price.

\section{Attribute importance}

Conjoint analysis also allows one to determine the relative importance of each attribute. This is done by considering how much difference each attribute could make to the total utility of a product. This difference is the range of the particular attribute's utility values expressed as a percentage (Orme, 2002b). Consider the following figures(Table 4), which are based on the hypothetical information contained in Table 2:

Attribute importance is ratio scaled data (Orme, 2002b), which means that one can directly compare the importance of attributes with one another. It is also correct to state that an attribute with an importance of $20 \%$ is twice as preferred as an attribute with an importance of $10 \%$. Importance depends on the particular attribute levels chosen for a study. For example, with a narrow range of prices, the price attribute would be less important (Orme, 2002b). Curry (not dated) also points out that one should always qualify statements about the importance of attributes so that they read: "... for the attributes and levels tested, attribute $X$ has the greatest impact on buyers preference." Attribute importance is calculated at the level of the individual respondent and can therefore be used as input in cluster analysis in order to identify segments of respondents with similar importance values (Hair et al, 1998:434).

The results for this study (obtained from the analysis done by the CVA 2.0 program) indicate that, for the attributes and levels tested, the style attribute had the highest average importance value (44,98 percent), followed by price $(25,89$ percent), retail store $(16,52$ percent) and brand (12,60 percent).

\section{Inferential statistics}

\section{Primary hypothesis}

The results of Kolmogorov-Smirnov tests and the visual inspection of histograms and normal probability plots indicated that the attribute importance for brand, style, retail outlet and price were decidedly non-normally distributed. The two-tailed p-values of the Kolmogorov-Smirnov tests were all less than 0,0005 .

Consequently, the non-parametric Friedman's test was used to test for significant differences in attribute importance. Friedman's test is a non-parametric alternative to repeated measures ANOVA (Green et al, 1999: 385). The results of the Friedman test $\left(c^{2}=\right.$ 157,78 with $3 \mathrm{df}, \mathrm{n}=227$, 2-tailed $\mathrm{p}$-value $<0,000$ ) indicated that two or more of the attribute importance differs significantly. Next a series of follow-up Wilcoxon's Signed Ranks tests were conducted to test for significant differences between all pairs of attribute importance. A Bonferroni correction was applied to control for Type I errors across these comparisons.
The results of these tests are shown in Table 5.

All the follow-up Wilcoxon Signed Ranks tests had significant $p$-values, even when judged against a Bonferroni correction of $0,0083(0,05 / 6=0,0083)$. These results indicate that there is a significant difference between the importance female consumers ascribe to brand, style, retail outlet and price as attributes of apparel when purchasing decisions are made. The primary hypothesis $\left(\mathrm{H}_{\mathrm{a}}\right)$ can therefore be accepted.

Secondary hypotheses The first four secondary hypotheses sought to determine whether there are significant differences in the attribute importance of style, brand, price and retail outlet respectively between the various age groups included in the study. Respondents were placed in one of five age groups. Table 6 shows the average attribute importances for these five age groups. One respondent did not indicate her age and was excluded from the analysis.

A series of Kolmogorov-Smirnov tests were conducted to test whether the attribute importance have normal distributions in each of the age groups. These analyses, as well as a visual inspection of histograms and normal probability plots, indicated that the attribute importance generally did not have normal distributions. As a result, the non-parametric Kruskal-Wallis test was used to test for significant differences in the attribute importance across the five age groups. The Kruskal-Wallis test is a non-parametric alternative to one-way ANOVA (Green et al, 1999: 371).

Four Kruskal-Wallis tests were conducted (one for each of the attributes) across the 5 age groups mentioned in Table 6 . The results are summarised in Table 7 .

The results of the Kruskal-Wallis tests were significant for two attributes, namely style and price. Based on these findings, $\mathrm{H}_{1}$ and $\mathrm{H}_{3}$ are accepted, while $\mathrm{H}_{2}$ and $\mathrm{H}_{4}$ are rejected. Respondents in the various age groups therefore differ significantly in their opinions with regard to the importance of style and price when buying decisions are made.

Follow-up Mann-Whitney $U$ tests were conducted next to determine where these significant differences could be found. A Bonferroni correction was applied to control for Type I errors across these comparisons. Test results were judged against an adjusted significance level of $0.0025(0,05 / 20=0,0025)$. The results of these tests are summarised in Table 8 for the style attribute and in Table 9 for the price attribute.

As Tables 8 and 9 indicate, the significant differences in the style and brand attributes are found to lie in the 16-20 age categories when compared with the other age groups. Young consumers appear to be more style-conscious and less price-sensitive than older consumers.

The last four secondary hypotheses $\left(\mathrm{H}_{5}-\mathrm{H}_{8}\right)$ sought to determine whether there are significant differences 
TABLE 7: $\quad$ TESTS RESULT FOR DIFFERENCES IN ATTRIBUTE IMPORTANCE ACROSS FIVE AGE GROUPS

\begin{tabular}{|l|c|c|c|c|}
\hline \multicolumn{1}{|c|}{ Test statistics } & Style & Brand & Price & Retail store \\
\hline Chi-Square & 40,36 & 4,92 & 41,55 & 1,74 \\
\hline df & 4 & 4 & 4 & 4 \\
\hline 2-tailed p-values & $<0,000$ & 0,295 & $<0,000$ & 0,783 \\
\hline
\end{tabular}

TABLE 8:

TWO-TAILED P-VALUES OF FOLLOW-UP MANN-WHITNEY U TESTS FOR STYLE

\begin{tabular}{|l|c|c|c|c|}
\hline \multicolumn{1}{|c|}{ Age groups } & $\mathbf{2 1 - 3 0}$ & $\mathbf{3 1 - 4 0}$ & $\mathbf{4 1 - 5 0}$ & $\mathbf{5 1 +}$ \\
\hline $16-20$ & 0,0000 & 0,0011 & 0,0000 & 0,0001 \\
\hline $21-30$ & - & 0,0969 & 0,2162 & 0,9307 \\
\hline $31-40$ & & - & 0,7627 & 0,1951 \\
\hline $41-50$ & & & - & 0,2555 \\
\hline $51+$ & & & & - \\
\hline
\end{tabular}

TABLE 9:

TWO-TAILED P-VALUES OF FOLLOW-UP MANN-WHITNEY U TESTS FOR PRICE

\begin{tabular}{|l|c|c|c|c|}
\hline \multicolumn{1}{|c|}{ Age groups } & $\mathbf{2 1 - 3 0}$ & $\mathbf{3 1 - 4 0}$ & $\mathbf{4 1 - 5 0}$ & $\mathbf{5 1 +}$ \\
\hline $16-20$ & 0,0000 & 0,0001 & 0,0000 & 0,0000 \\
\hline $21-30$ & - & 0,4510 & 0,9541 & 0,3052 \\
\hline $31-40$ & & - & 0,6299 & 0,1414 \\
\hline $41-50$ & & & - & 0,3020 \\
\hline $51+$ & & & & - \\
\hline
\end{tabular}

TABLE 10: AVERAGE ATTRIBUTE IMPORTANCE FOR THE TWO EXPENDITURE CATEGORIES IN THE STUDY

\begin{tabular}{|l|c|c|c|c|c|}
\hline \multicolumn{1}{|c|}{$\begin{array}{c}\text { Monthly expenditure on clothing } \\
\text { items }\end{array}$} & $\mathbf{n}$ & Brand & Style & $\begin{array}{c}\text { Retail } \\
\text { store }\end{array}$ & Price \\
\hline$<$ R500 & 142 & 12,11 & 44,04 & 15,58 & 28,27 \\
\hline R500 or more & 85 & 13,43 & 46,56 & 18,10 & 21,92 \\
\hline Total & 227 & 12,60 & 44,99 & 16,52 & 25,89 \\
\hline
\end{tabular}

TABLE 11: RESULTS OF MANN-WHITNEY U TESTS FOR DIFFERENCES IN ATTRIBUTE IMPORTANCES ACROSS TWO EXPENDITURE GROUPS

\begin{tabular}{|l|c|c|c|c|}
\hline \multicolumn{1}{|c|}{ Test results } & Brand & Style & Retail store & Price \\
\hline Mann-Whitney U & 5342 & 5671 & 5168 & 4956,5 \\
\hline Wilcoxon W & 15495 & 15824 & 15321 & 8611,5 \\
\hline Z & $-1,447$ & $-0,760$ & $-1,811$ & $-2,252$ \\
\hline 2-tailed p-values & 0,148 & 0,447 & 0,070 & 0,024 \\
\hline
\end{tabular}


in the attribute importance of style, brand, price and retail outlet respectively between respondents grouped into two categories on the basis of their monthly expenditure on apparel items. Table 10 shows the average attribute importance for these two expenditure categories.

The tests conducted for normal distributions in each of the expenditure groups indicated that the attribute importance generally did not have normal distributions. As a result, the non-parametric Mann-Whitney $U$ test was used to test for significant differences in attribute importance between the two expenditure groups. The Mann-Whitney $U$ test is a non-parametric alternative to the independent samples t-test (Green et al, 1999:359).

A Bonferroni correction was applied to control for Type I errors across these comparisons. Test results were judged against an adjusted significance level of $0,0125(0,05 / 4=0,0125)$. The results of these tests are summarised in Table 11.

The findings in Table 11 indicate that respondents in the two expenditure groups do not differ significantly with respect to the value they attach to the attributes of apparel when buying decisions are made. Hypotheses 5 to 8 are therefore rejected.

\section{CONCLUSIONS AND IMPLICATIONS}

Trends in the apparel industry are changing rapidly and marketers are not always certain how the market will accept the latest trend. A new trend can sometimes turn out to be no more than a fad - a very shortlived trend and in that case retailers and manufacturers would lose money. Other trends turn out to be classics, where the demand grows and stabilises. An understanding of female buying behaviour, and specifically of what women value when apparel purchase decisions are made, can be of great value to marketers.

The results of this study indicate that style is the most important attribute of apparel to women when making purchasing decisions, with price being the second most important attribute. It can also be concluded that there is a relationship between age and style as well as between age and brand. This will have implications for a manufacturer who is targeting a specific age group. However, no relationship was found between age and retail outlet or between monthly expenditure and brand or retail outlet. The insight gained from this study could help apparel manufacturers and retailers to:

- understand consumers' selection criteria when purchasing apparel

- plan their merchandise mix more efficiently

- plan their promotional messages and strategies better

- refine their training strategies for sales associates

This information could also be used for the develop- ment of a theoretical model towards understanding consumer apparel purchasing decisions. There is a definite lack in theoretical knowledge in the models that explain what is important to consumers concerning apparel purchase decisions, and specifically how they make trade-offs between various product attributes when purchasing decisions for apparel are made. Marketers may find it useful to investigate the possibility of using the attribute importance construct as a means of segmenting future markets. Special attention should be given to older female buyers. Future studies in this field could investigate the differences in attribute importance for apparel among consumers in various cultural groups. Studies could also be done to determine how male consumers value various attributes in clothing items before purchases are made.

\section{REFERENCES}

ANTONIDES, G \& VAN RAAIJ, WF. 1998. Consumer Behaviour. A European Perspective. Chichester. John Wiley.

AURET, F de T. 1990. An investigation into the needs and purchasing behaviour of female students at the University of Stellenbosch with a view to the establishment of a new enterprise marketing leisure wear. Unpublished MBA Dissertation. University of Stellenbosch.

BEAUDOIN, P, MOORE, MA \& GOLDSMITH, RE. 2000. Fashion leaders' and followers' attitudes toward buying domestic and imported apparel. Clothing and Textiles Research Journal 18(1):56-64.

BRANNON, EL. 2000. Fashion Forecasting. New York. Fairchild.

BURGER, C \& HERBST, F. 2002. Attributes used by young consumers when assessing a fashion product: A conjoint approach. Journal of Family Ecology and Consumer Sciences 30:40-45.

BURNS, LD \& BRYANT, N. 1997. The Business of Fashion. New York. Fairchild.

CAMPBELL, L \& BUTANEY, GT. 1996. Market segmentation: using demographics, psychographics and other niche marketing techniques to predict customer behaviour. Journal of Consumer Marketing 13(2):5861.

CASSILL, NL \& DRAKE, MF. 1987. Apparel selection criteria related to female consumers' lifestyle. Clothing and Textiles Research Journal 6(1):20-28.

CURRY, J. Not dated. Conjoint analysis: after the basics. [Online] Available from http://www.sawtooth.com/news/library/articles/basics. htm [Accessed:2003-02-19]

DILLON, WR, MADDEN, TJ \& FIRTLE, NH. 1993. Essentials of Marketing Research. Homewood, Illinois. Irwin.

ECKMAN, M, DAMHORST, ML \& KADOLPH, SJ. 1990. Toward a model of the in-store purchase decision process: consumer use of criteria for evaluating women's apparel. Clothing and Textiles Research Journal 8(2):13-22.

FORSYNTHE, SM. 1993. Effect of private, designer, and national brand names on shoppers' perception of apparel quality and price. Clothing and Textile Re- 
search Journal 9(2):1-6.

GREEN, SB, SALKIND, NJ \& AKEY, TM. 1999. Using SPSS for Windows: Analysing and Understanding Data. $2^{\text {nd }}$ ed. Upper Saddle River, New Jersey. Prentice-Hall International.

GREEN, PE \& SPIRNIVASAN, V. 1990. Conjoint analysis in marketing: new developments with implications for research and practice. Journal of Marketing 54:3-19.

HAIR, JF, ANDERSON, RE, TATHAM, RL \& BLACK, WC. 1998. Multivariate Data Analysis. $5^{\text {th }}$ ed. Upper Saddle River, New Jersey. Prentice-Hall International. HUDDLESTON, P \& CASSILL, NL. 1990. Female consumers' brand orientation: the influence of quality and demographics. Home Economics Research Journal 18(3):255-262.

LANG, JQ \& CROWN, EM. 1993. Country-of-origin effect in apparel choices: A conjoint analysis. Journal of Consumer Studies and Home Economics 17:87-98. LEVY, M \& WEITZ, BA. 1998. Retailing Management. $3^{\text {rd }}$ ed. Boston. Irwin McGraw-Hill.

MCDANIEL, C \& GATES, R. 2001. Marketing Research Essentials. $3^{\text {rd }}$ ed. Cincinnati, Ohio. SouthWestern College Publishing.

ORME, BK. 1998. Sample size issues for conjoint analysis studies. Sawtooth Software.

ORME, BK. 2002a. Analysis of Traditional Conjoint Using Microsoft Excel ${ }^{\mathrm{TM}}$ : An Introductory Example. Sawtooth Software Research Paper Series. [Online] Available from http://www.sawtoothsoftware.com [Downloaded: 2003-02-19].

ORME, BK. 2002b. Interpreting Conjoint Analysis

Data. Sawtooth Software Research Paper Series.
[Online] Available from http://www.sawtoothsoftware.com [Downloaded: 2003-02-19].

OPPEWAL, H \& VRIENS, M. 2000. Measuring perceived service quality using integrated conjoint experiments. The International Journal of Bank Marketing 18(4):154-169.

PERNA, R. 1987. Fashion Forecasting. New York. Fairchild.

RUTTER, N \& EDWARDS, O. 1999. Ready to Ware. Forbes 163(7):30-33.

SAWTOOTH SOFTWARE. 1996. CVA System Version 2.0. Washington. Sequim.

SHETH, JN \& SOSODIA, RS. 1999. Revisiting marketing's lawlike generalizations. Journal of the Academy of Marketing Science 27(1):1-87.

SHIM, S \& KOTSIOPULOS, A. 1993. A typology of apparel shopping orientation segments among female consumers. Clothing and Textiles Research Journal 12(1):73-85.

SUDMAN, S \& BLAIR, E. 1998. Marketing Research. Sydney. McGraw-Hill.

SWEENEY, JC \& SOUTAR, GN. 2001. Consumer perceived value: The development of a multiple item scale. Journal of Retailing 77:203-220.

TERBLANCHE, RM. 1990. A lifestyle typification of female students, with specific reference to fashion awareness and clothing orientation. Unpublished MEcon-dissertation: University of Stellenbosch, South Africa.

VAN DER POL, M \& RYAN M. 1996. Using conjoint analysis to establish consumer preferences for fruit and vegetables. British Food Journal 98(8):5-12. 